\title{
DOUBLE N EARTHMOVERS LTD. V. EDMONTON (CITY OF): THE EROSION OF THE LAW OF TENDERING AS SET OUT IN R. V. RON ENGINEERING \& CONSTRUCTION (EASTERN) LTD.
}

DON J. MANDERSCHEID, Q.C.

\section{INTRODUCTION}

For over a quarter century, lawyers and judges alike have deciphered the tender process based upon the "Contract A/Contract B" analysis as first espoused by Estey J. in $R$. v. Ron Engineering \& Construction (Eastern) Ltd.' In accordance with that analysis, the tendering process involved two distinct contracts. The first contract was a "unilateral contract" that Estey J. termed "Contract A." This contract was the initial contract created by the owner's offer to receive bids from prospective bidders. Acceptance of this offer was the submission of a bid by a bidder in response to the owner's offer. This initial contract was created between the owner and each and every bidder. Once the owner had selected the successful bidder, a further contract termed "Contract B" was to be entered into between the owner and such party. This latter contract was to be the written agreement between the owner and the successful bidder and was to embody Contract A by including the terms specified by the owner and the price specified by the bidder. ${ }^{3}$

Subsequent to Ron Engineering, the Supreme Court of Canada has had further opportunities to refine the Contract A/Contract B analysis. This is particularly so in cases that have considered the issue of non-compliance by bidders in regards to Contract $A$. In this respect, the leading case is the Court's decision in M.J.B. In that case, the central issue addressed by the Court was whether the inclusion of a "privilege clause" in the tender documents permitted the owner to disregard the lowest bid in favour of another bid, including a non-compliant one. ${ }^{5}$ In deciding the issue, Jacobucci J. concluded that there was an implied term in Contract A that only a compliant bid would be accepted, ${ }^{6}$ and that such an implied obligation on the part of the owner could not be circumvented by a privilege clause.'

As of late, it was believed that the law germane to the principles of the Contract A/Contract $B$ analysis as laid down in Ron Engineering, and the implied obligation to accept only a compliant bid as set out in M.J.B., were fairly well settled. Nonetheless, just when you think that the judiciary has exhausted all issues pertinent to a subject, a case comes along to challenge the fundamental underpinnings of the relevant law. Most recently, that case has presented itself in the Supreme Court of Canada decision in Double N Earthmovers Lid. $v$. Edmonton (City of). ${ }^{\text {. }}$

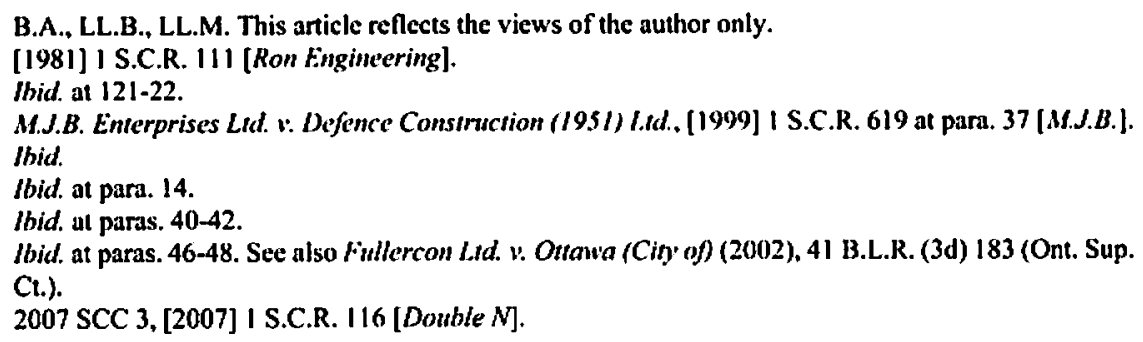




\section{DOUBLEN}

\section{A. THE FACTS}

The facts in Double $N$ concerned a call for tenders that had been issued by the City of Edmonton (City), some twenty years earlier. At that time the City had sought bids on a thirtymonth contract to supply equipment and operators to move refuse at a waste disposal site. The City's tender documents specified that all equipment required to complete the work contemplated in the tender was to have a manufacture year of 1980 or newer. The City's tender documents further required that the serial number and the City's licence registration number be provided for every piece of equipment and that failure to comply "either in whole or in part may invalidate the bid" and that the "City reserves the right to reject any and all Tenders, and to waive any informality therein."

In response to its tender, six bids were received by the City; however, only the four lowest bids were considered. After opening the bids, two bids were disqualified by the City, leaving only the bids by Sureway Construction of Alberta Ltd. (Sureway) and Double N Earthmovers Lid. (Double N). Of these two bids, Sureway's bid was the lowest. Sureway's bid had indicated its equipment had manufacture year of 1980 or newer. Although the stated Sureway equipment had a manufacture year of 1980, the serial number and the City's license registration number listed corresponded in one case with a caterpillar bulldozer manufactured in 1979, and in another with a caterpillar bulldozer manufactured in 1977.

Subsequent to opening the bids and eliminating the unacceptable bids, the City commenced separate negotiations with Sureway and Double N. During the course of these negotiations, the City managed to have both Sureway and Double $\mathrm{N}$ lower their respective bids. Prior to the contract award, Double $\mathrm{N}$ had informed the City that Sureway did not own 1980 or newer equipment. The City chose not to investigate the matter. In the end, the Sureway bid was considered the lowest and the City awarded the contract to Sureway. After signing the contract, Sureway indicated to the City that it would be supplying equipment that did not meet the 1980 requirement. In response, the City did not pursue the matter further. Although Sureway eventually rectified the situation by supplying equipment that met the 1980 age requirement, some of the work had been performed by the pre-1980 equipment throughout the duration of the contract. Consequently, Double $\mathrm{N}$ claimed that the City breached the duties owed to it under the bidding contract (Contract $A$ ) and sued for the profits it would have realized had it been awarded Contract $B$.

At trial, Marceau J. dismissed Double N's claim. ${ }^{10}$ In the opinion of the learned justice, Sureway's bid was compliant and he found no duty on the part of the City to investigate Sureway's bid. Furthermore, he did not find that the City was in breach of Double N's Contract $\mathrm{A}$ by deciding, after accepting Sureway's bid, to let Sureway use equipment of an older manufacture date than 1980 . In his view, all of Contract $A$ came to an end upon the valid formation of Contract B with Sureway, and the City could not be liable to Double N

11) Double N Earthmover Lid. v. Edmonten (Cin' of), 1998 ABQB 31, 213 A.R. 81. 
for any dealings the City may have had with Sureway subsequent to the formation of Contract B.

Double $\mathrm{N}$ appealed to the Court of Appeal for Alberta." Its appeal was dismissed unanimously. Justice Russell, on behalf of the Court, agreed with the trial judge that Sureway's bid was compliant on its face, and that an owner is not subject to a duty to investigate suspicions of potential non-compliance. Justice Russell also rejected Double N's argument that the City's Contract $A$ obligations with an unsuccessful bidder could survive the formation of Contract B with a compliant bidder.

Double $\mathrm{N}$ appealed to the Supreme Court of Canada, where once again the appeal was dismissed. In its judgment, the Court was split five in favour (LeBel, Deschamps, Fish, Abella, and Rothstein JJ.) and four in dissent (McLachlin C.J.C., Bastarache, Binnie, and Charron JJ.). This case comment proposes to discuss the Court's decision in Double N, and the ramifications, if any, that emanate from this decision $v i s-\dot{a}-v i s$ the law of tendering as laid down in Ron Engineering.

\section{B. DeCISION - ISSUES AND ANALYSIS}

\section{DECISION OF THE MAJORITY}

In dismissing the appeal, Abella and Rothstein JJ. for the majority concluded first that "Double N's bid received fair treatment throughout the bidding process."12 Second, they opined that "Sureway's bid offered units that were compliant on their face and open to acceptance by the City."'13 Third, "the City was not aware of Sureway's deceit until after accepting" Sureway"s bid, and it had not colluded with Sureway "during the bidding process to perpetrate unfairness towards other bidders." ${ }^{14}$ Last, once the City awarded the contract to Sureway, its "failure to supply as promised became a matter" solely between the City and Sureway. ${ }^{15}$ As such, in accordance with the terms of Contract B, the City was entitled to deal with Sureway's obligations as it saw fit.

\section{ISSUES AND ANALYSIS}

\section{a. Did the City Accept a Non-Compliant Bid?}

In regards to this issue, Abella and Rothstein JJ. ruled that the City did not accept a non-compliant bid. In this sense, the Justices noted that Sureway promised on the face of its bid to supply equipment that had a manufacture year of 1980 or newer, and this is what the City accepted when it awarded the contract to Sureway. Furthermore, Condition 17 of the Conditions of Tender made bidders aware that not every failure to comply with the tender requirements would invalidate a bid. As such, the absence of the licence and serial numbers for the Sureway equipment in Sureway's bid is precisely the sort of informality which would 
not materially affect the price or performance of Contract $B$. Therefore, as the provision of licence and serial numbers was not an essential term of the tender documents, they were capable of being waived by the City. ${ }^{16}$

\section{b. Did the City Have a Duty to Investigate Sureway's Bid?}

Justices Abella and Rothstein concluded that the City did not breach any duties owed to Double $\mathrm{N}$ by failing to investigate Sureway's bid. In coming to this conclusion, they reasoned that as each bidder is legally obliged to comply if its bid is accepted, there is no reason why bidders would expect an owner to investigate whether a bidder will comply. As well, there was neither an express nor an implied obligation in the tender documents to investigate the equipment that was stated in the bid prior to acceptance. ${ }^{17}$ In reaching this conclusion, Abella and Rothstein JJ. relied upon an observation made by Russell J.A. at the Court of Appeal:

But in the absence of a term in contract $A$ to investigate the bidder's capacity to comply with the terms of the tender, once an owner accepts in good faith a tender which is compliant on its face in all material terms, all obligations to other bidders are discharged. Were that not so, parties to contract $B$ might be subject to constant surveillance and scrutiny of other bidders, challenging any deviation from the original terms of contract $A$, thereby ultimately frustraling the tendering industry generally, and introducing an element of uncertainty to contract $\mathrm{B}^{18}$

In the end result, both Justices concurred with Russell J.A., and held that allegations raised by rival bidders in regards to compliance with the terms of Contract $A$ should not compel owners to investigate the bids made by others, as to do so would "frustrate, rather that enhance, the integrity of the bidding process."19

\section{c. Did the City Engage in Impermissible "Bid Shopping"?}

With respect to this issue, Abella and Rothstein JJ. held that the City's pre-award negotiations did not amount to "bid shopping." In reaching this conclusion, the Justices referenced two judicial definitions of this concept. The first simply defines "bid shopping" as, "the practice of soliciting a bid from a contractor, with whom one has no intention of dealing, and then disclosing or using that in an attempt to drive prices down amongst contractors with whom one does intend to deal." ${ }^{20}$ The second definition provides a broader description of the practice of "bid shopping" as consisting of, "conduct where a tendering authority uses the bids submitted to it as a negotiating tool, whether expressly or in a more clandestine way, before the construction contract has been awarded."21

lbid. at paras. 34-45.

Ibid. at paras, $47,49-51$.

Double $N$ (C.A.), supra note 11 at para. 56.

Double $N$, supra note 8 at para. 53.

Supra note Il at para. 56, referring to Naylor Group /nc. v. Ellis-Don Construction Lrd., 2001 SCC 58, [2001] 2 S.C.R. 943 at para. 9, quoting Langdon J. in Naylor Group Inc. v. Ellis-Don Construction Ifd. (1996), 30 C.L.R. (2d) 195 at para. 13.

Double N, ibid, referring to Stanco Projects Lid. v. British Columbia (Ministry of Water, Land and Air Protection), 2004 BCSC 1038, 242 D.L.R. (4th) 720 at para. 100. 
In determining whether or not bid shopping had indeed occurred, Abella and Rothstein JJ. considered Double N's argument that the wording of the subject tender documents prohibited what had transpired in the present case. In support of their argument, Double $\mathrm{N}$ relied upon the ruling of lacobucci $J$. in M.J.B., where the latter stated that, "[t]he rationale for the tendering process, as can be seen from these documents, is to replace negotiation with competition."22 In dismissing this argument, the Justices noted that the decision in M.J.B. "makes clear that the tender documents control the contractual obligations of the parties to a tender, and lacobucci J.'s observations were based on the particular documents in that case." ${ }^{23}$

In this regard, Abella and Rothstein JJ. drew attention to the fact that the wording of Condition 25 of the tender documents, specifically stated that, "Changes in Tenders will not be permitted after the Tenders have been opened, unless negotiated with the lowest evaluated Tenderer." 24 In light of this wording, the Justices concluded that some measure of negotiation between the City and the bidders was clearly contemplated after the City's initial evaluation had taken place. ${ }^{35}$ The City was therefore not guilty of bid shopping as it was specifically entitled by its conditions of tender to negotiate with the lowest compliant bidder. Accordingly, the exercise of this right by the City was not to be construed as a breach of Contract A with Double N.

\section{d. Did the City Award the Contract to Sureway on Terms Other than} Those Set out in the Tender Documents?

Justices Abella and Rothstein held that the City did not enter into a contract on terms other than those set out in the bidding documents and therefore, the City did not breach any duties owed to Double N. In making this determination, the Justices made two observations. First, when the City communicated to Sureway its acceptance of Sureway's bid, Sureway had by its bid promised to supply 1980 equipment. Second, and more importantly, although Sureway was subsequently found to be deceitful with respect to this equipment, this untruth was unknown to the City until after it had accepted Sureway's bid. Given this fact, there was no collusion between the City and Sureway to disregard the tender terms.

\section{e. Did the City Violate its Duties to Double $\mathrm{N}$ by Permitting}

Sureway to Supply Equipment Manufactured Prior to 1980?

With respect to this issue, Double $\mathrm{N}$ had maintained that by entering into Contract $\mathrm{B}$ with Sureway, the City had breached its duties owed to Double $N$ under Contract $A$ by permitting Sureway to supply equipment manufactured prior to 1980 . From the perspective of Double $\mathrm{N}$, such conduct amounted to a waiver by the City of a fundamental term of Contract $\mathrm{B}$. For that reason, Double $N$ held to the belief that the City was obliged to either require Sureway to perform its contractual obligations, or alternatively, to exercise its right under Condition 9 to cancel the contract with Sureway. In the event of cancellation, Double $\mathrm{N}$ argued that the 
City must re-tender, abandon the contract or, as Double $\mathrm{N}$ was the next lowest bidder, award the contract to it.

In considering Double N's argument, Abella and Rothstein JJ. were required to consider whether the owner's obligations under Contract $A$ to unsuccessful bidders, and in particular, its implied obligation to treat all bidders fairly, survives the creation of Contract B with the successful bidder. In their opinion it did not. In this sense, the Justices based their conclusion on the fact that the conduct Double $N$ complained of, that being the waiver by the City of the 1980 manufacture year requirement, actually occurred after the award of Contract $B$. For that reason, where an owner undertakes a fair evaluation and enters into Contract $B$ on the terms set out in the tender documents, Contract $A$ is fully performed and any obligations on the part of the owner to unsuccessful bidders are deemed to have been fully discharged. Contract $B$ is a distinct contract to which the unsuccessful bidders are not privy to.

It should be noted that in reaching their decision, Abella and Rothstsein JJ. placed specific reference on the fact that by Condition 9 of Contract $B$, a right of cancellation was conferred on the City, but that such right was permissive and not obligatory. ${ }^{26}$

\section{DECISION OF THE DISSENTING JUDGES}

The decision of the dissenting justices was delivered by Charron J., who labelled the reasoning of the trial judge and that of the Court of Appeal as being "circular."27 From her perspective, on the one hand, the Courts below had held that a bid can be regarded as compliant at the Contract A stage because the owner can always insist on compliance with the terms of the tender. Still, on the other hand, these same Courts have held that the owner does not need to insist on compliance with the terms of the tender at the Contract $B$ stage based on the fact that it has accepted a compliant bid at the Contract $A$ stage. Justice Charron was of the opinion that "this reasoning completely nullifies the protection afforded by the implied obligation to accept only a compliant bid." 28 She therefore held that the City breached its obligation to accept only a compliant bid at the Contract $A$ stage of the tender process. Furthermore, in her view, the City breached its duty to treat all bidders equally and fairly when it failed to insist on compliance with the age requirement in awarding Contract B to Sureway.

The crux of the Charron J's conclusion was aptly stated in the following paragraph:

The right to insist on compliance cannot tum what is on its face a non-compliant bid into a compliant one. Furthermore, I fail to see how the integrity of the bidding process is protected by allowing a bidder to get rid of the competition unfairly and then hash it out with the owner after it has been awarded the contract. Approaching the tendering process in this manner encourages precisely the sort of duplicity seen in the present appeal. A bidder can submit a bid that is either ambiguous or deliberately misleading but compliant on its face in some respects, secure in the knowledge that if it is awarded Contract $B$ it will be in a strong position to renegotiate essential terms of the contract. And an owner can reason that it may be best not to 
resolve any ambiguity before awarding Contract B, since at that time all Contract $A$ obligations towards other bidders will terminate and it can then enter into renegotiations with the successful bidder without fear of liability. This approach is not consistent with a fair and open process. ${ }^{29}$

\title{
III. Discussion
}

The writer fully concurs with the decision of the majority in Double $N$ with respect to the issues relative to the City's acceptance of a non-compliant bid, the allegation of bid shopping, and the awarding of the contract to Sureway on terms other than those set out in the tender documents. However, in terms of the issues that relate to the City's duty to investigate Sureway's bid, and whether the City violated its duties to Double $N$ by permitting Sureway to supply equipment manufactured prior to 1980 , the writer, with all due deference to the learned Justices who ruled with the majority, cannot fully concur with their logic and conclusion.

With respect to the issue of whether the City had a duty to investigate Sureway's bid, perhaps a more appropriate reasoning would be to follow the dissenting judgment of Charron J. In this sense, Charron J. maintained that "the obligation to accept only a compliant bid requires that reasonable steps be taken to evaluate the bid for compliance before acceptance. ${ }^{30}$ In describing the extent to which an owner is obligated to take such "reasonable steps," Charron J. stated that:

Russell J.A. on behalf of the Court of Appeal expressed concem about imposing any "duty ... to investigate" on the owncr, stating:

To impose a duty on owners to investigate whether a bidder will comply with the terms of its bid would overwhelm and ultimately frustrate the tender process by creating unwelcome uncertainties.

\begin{abstract}
Abella and Rothstein JJ. agree with this observation, and I acknowledge that an owner does not have to launch an investigation to satisfy itself that a bidder will in fact do what it undertakes to do. Nor do I claim that an owner has a duty, in its evaluation of the bids, to search for additional information or to take action beyond that which it is empowered to take pursuant to the tender documents themselves. But this does not mean that the owner does not have an obligation to take reasonable steps to evaluate the terms of the bid to ensure that they conform with the tender call." ${ }^{31}$
\end{abstract}

When considering the obligation to take "reasonable steps" to ensure bid compliance, it is to be noted that in the context of the facts in Double $N$, other information was to be provided in addition to the year of manufacture of the equipment. In this respect, the serial number and City registration licence number of such equipment was also to be provided. Had the City taken "reasonable steps" to assure itself that the bid was compliant through verification of such information, it would have easily discovered Sureway's non-compliance

Ibid. at para. 119 [emphasis in original, references omitted]. 
as to equipment year. The City could then have rejected Sureway's bid for non-compliance and awarded the contract to Double $\mathrm{N}$, without attending legal repercussions.

As maintained by Charron J., the requirement to take "reasonable steps" at the bid evaluation stage does not require a wholesale investigation or search for additional information. Nevertheless, each case must be determined on its own facts. For that reason, what may be a reasonable expectation of review as to bid compliance in one case may be totally inappropriate in another. Accordingly, if the facts support the imposition of a duty to take "reasonable steps" at the bid evaluation stage, as was the case in Double $N$, such a requirement should protect rather than compromise the tender process. Regrettably, in the case of Double $N$, due to the absence of such a duty, two decades of costly litigation has ensued, culminating in the creation of a problematic legal precedent.

With respect to the issue of whether the City violated its duties to Double $\mathrm{N}$ by permitting Sureway to supply equipment manufactured prior to 1980 , a determination of this issue is dependant upon a clarification of the law vis-à-vis the fate of Contract $A$ once Contract $B$ has been entered into. ${ }^{32}$ Ron Engineering and the successor pronouncements from the Supreme Court that followed this case had previously failed to address this need for clarification. Given the facts in Double $N$, and the statements contained in previous Supreme Court decisions such as M.J.B. and Martel Building Ltd. v. Canada, ${ }^{33}$ it was hoped that the Court would, in Double N, provide this clarity. Unfortunately, in concluding that Contract $A$ and Contract B are to be treated as two distinct contracts, the majority in Double $N$ have completely nullified the logic of the "Contract A/Contract B" analysis as enunciated by Estey $\mathrm{J}$. in Ron Engineering.

In this sense, it has always been the writer's assumption that the reasoning in Ron Engineering turns on the understanding that Contract $A$ and Contract $B$ are inextricably linked, with the one merely being the precursor of the other. Contract $A$ sets out what is required by the owner in terms of the tender and corresponding bid. Contract $B$ is merely a migration and codification of the terms of Contract $A$ in a legally binding format. Stated another way, Contract $A$ sets in motion the tender process and with the acceptance of a compliant bid by the owner, Contract B will complete the work that was the subject of the tender. This fact was acknowledged by lacobucci J. in M.J.B.:

A tender, in addition to responding to an invitation for tenders, is also an ofler to perform the work outlined in the plans and specifications for a particular price. The invilation for tenders is therefore an invitation for oflers to enter into Contract $B$ on the terms specified by the owner and for a price specified by the contractor. The goal for contractors is to make their bid as competitive as possible while still complying with the plans and specifications outlined in the tender documents. ${ }^{34}$

See Double N (C.A.), supra note 11 at paras. 49-50, where Russcll J.A. recognized the fact that, "Ron Engineering does not address, either implicitly or explicilly, the issue of what happens to contracts $A$ upon the formation of contract B.... No other cases have been cited which suggest that contract $B$ terminates all contracts $A . "$

") M.J.B., supra note 3; 2000 SCC 60, [2000] 2 S.C.R. 860,

3. M.J.B., ibid. at para. 37. See also Cityscape Contracting Lid. v. Edmonton (City of), 2007 ABQB 161, 71 Alta. L.R. (4th) 175 at para. 36, where Trussler J. references this conclusion as stated in Double $N$, supra note 8. 
If the decision of the majority in Double $N$ were to be accepted literally, an unscrupulous bidder could arguably circumvent the tender process by submitting what on its face resembles a compliant bid, when in reality that the bidder knows it is not. Once Contract B has been entered into, the deceitful bidder could merely confess the shortcomings of its bid to the owner and run the risk that the owner would not cancel the contract. In addressing such a potential situation, the majority reasoned that the potential for cancellation of the contract by the owner would be a sufficient deterrent to such abuse. ${ }^{35}$ This reasoning may prove sound in a depressed market, however, in a rising market, most likely the owner would be willing to continue with Contract B, as was the case in Double N.

\section{Conclusion}

What was actually at stake in Double $N$ was the integrity of the tender process itself and the implied obligation to treat all bidders fairly. ${ }^{36}$ This fact was aptly stated by Charron $\mathrm{J}$. as follows:

This is the cautionary tale of a tendering process gone badly wrong. Although in some business contexts parties might decide to tum a blind cyo to contractual inaccuracies and ambiguities, the tendering process is different. It is a process in which faimess and integrity are of paramount importance. Owners spend large amounts of money composing and issuing tenders, and bidders spend large amounts of money formulating and submitting bids. ${ }^{37}$

The relevancy of the decision of the Supreme Court of Canada in Double $N$, regarding the law of tendering and, in particular, its ramifications vis- $\dot{a}-v i s$ the Contract A/Contract B analysis as set out in Ron Engineering, may prove profound. ${ }^{3 \mathrm{H}}$ If future rulings of the Court continue to follow the reasoning in Double $N$, one may assume that these ramifications will manifest themselves by severely undermining the principles of fairness and integrity in the context of the tender process. The decision in Double $N$ has created a legal "loophole" in terms of permitting the potential for unfairness towards bidders during the Contract A stage and a forced compromise towards the owner at the Contract B stage. This is not a desirable state of affairs. Nevertheless, time will tell, and it is hoped that if, and when the Supreme Court is presented with a further opportunity to address this issue, that the foregoing discussion may be of assistance.

36 See Double N (C.A.), supra note II at para. 5I, where Russell J.A. reitcrates this principle by stating that. "[n]onetheless, decisions in Ron Engincering. M.J.R., and Martel offer guidance. Embedded in these decisions are two fundamental principles underlying the tender process: (1) the obligation to preserve the integrity of the lender process; and (2) the obligation to treat tenderers fairly and equally throughout the tender process."

" Double $N$, supra note 8 at para. 104.

38 See Chandos Consiruction Lid. v. Alberta (Alberta Infrastructure), [2006] S.C.C.A. No. 108, where the appeal to the Supreme Court of Canada was remanded back to the Court of Appeal to be dealt with in accordance with the decision in Double $N$. 